\title{
Emerging mould infections: Get prepared to meet unexpected fungi in your patient
}

\author{
Sarah Dellière ${ }^{1}$, Olga Rivero-Menendez ${ }^{2}$, Cécile Gautier ${ }^{3}$, Dea Garcia-Hermoso ${ }^{3}$, \\ Ana Alastruey-Izquierdo (D) 2 and Alexandre Alanio (D) 1,3,4,*
}

${ }^{1}$ Université de Paris, Laboratoire de Parasitologie-Mycologie, AP-HP, Groupe Hospitalier Saint-Louis-LariboisièreFernand-Widal, Paris, France, ${ }^{2}$ Mycology Reference Laboratory, National Centre for Microbiology, Instituto de Salud Carlos III, Majadahonda, Madrid, Spain, ${ }^{3}$ Institut Pasteur, Molecular Mycology Unit, CNRS UMR2000, National Reference Center for Invasive Mycoses and Antifungals (NRCMA), Paris, France and ${ }^{4}$ Department of Molecular Microbiology and Immunology, Johns Hopkins Bloomberg School of Public Health, Johns Hopkins University, Baltimore, Maryland, USA

*To whom correspondence should be addressed. Alexandre Alanio, MD, PhD, Molecular Mycology unit, Institut Pasteur, 25 rue du Dr Roux 75724 Paris Cedex 15. Tel: +33140613255; Fax: +33145688420; E-mail: alexandre.alanio@pasteur.fr

Received 18 December 2018; Revised 1 March 2019; Accepted 5 April 2019; Editorial Decision 29 March 2019

\begin{abstract}
Invasive fungal diseases are increasing issues in modern medicine, where the human immunodeficiency virus (HIV) pandemic and the wider use of immunosuppressive drugs generate an ever-growing number of immunocompromised patients with an increased susceptibility to uncommon fungal pathogens. In the past decade, new species have been reported as being responsible for disseminated and invasive fungal diseases in humans. Among them, the following genera are rare but seem emerging issues: Scopulariopsis, Hormographiella, Emergomyces, Westerdykella, Trametes, Actinomucor, Saksenaea, Apophysomyces, and Rhytidhysteron. Delay in diagnosis, which is often the case in these infections, jeopardizes patients' prognosis and leads to increased mortality. Here we summarize the clinical and biological presentation and the key features to identify these emerging pathogens and we discuss the available antifungal classes to treat them. We focused on Pubmed to recover extensively reported human invasive cases and articles regarding the nine previously cited fungal organisms. Information concerning patient background, macroscopic and microscopic description and pictures of these fungal organisms, histological features in tissues, findings with commonly used antigen tests in practice, and hints on potential efficient antifungal classes were gathered. This review's purpose is to help clinical microbiologists and physicians to suspect, identify, diagnose, and treat newly encountered fungi in hospital settings.
\end{abstract}

Key words: invasive fungal disease, emerging fungi, Emergomyces, Scopulariopsis, Hormographiella, Actinomucor, Apophysomyces, Rhytidhysteron, Saksenaea, Trametes, Westerdykella.

\section{Introduction}

Invasive fungal infections (IFIs) are increasing due to the growing use of immunosuppressive chemotherapy and the persistence of the AIDS pandemic in specific areas. In addition, the improvement of diagnostic means may concur to that trend. Candida spp. and Cryptococcus spp. are the most frequent isolated yeasts in human IFIs, while Aspergillus spp., Fusarium spp. and Scedosporium spp. are the most isolated moulds. ${ }^{1}$ However, the part attributed to other fungal organisms is increasing and emerging uncommon species responsible for IFIs are more frequently described around the world. In this review, we describe unusual emerging moulds responsible for IFIs with a focus on the fungus-morphology, environmental niche, location, mode of transmission-and on the infection (clinical presentation and treatments available). These genera and species where selected 
for their scarcity and their recent emergence during the past two decades.

\section{Actinomucor spp.}

The genus Actinomucor belongs to the order Mucorales and is commonly isolated from soil, from the rhizosphere of plants and from mouse and rabbit dung. ${ }^{2}$ Actinomucor elegans is involved in traditional fermentation of sufu, a cheese-like soybean very common in Asia. ${ }^{3}$ The only species of the genus Actinomucor is Actinomucor elegans. divided in var. elegans, var. kuwaitiensis, and var. taiwanensis, considered synonyms (http://www.indexfungorum.org). A. elegans has white to cream floccose cultures growing rapidly at $30^{\circ} \mathrm{C}$. Microscopically they are verticillately branched sporangiophores with terminate sporangia in various lengths. The smooth or spiny sporangia wall encloses spherical to ovoidal sporangiospores. ${ }^{4}$ Sequencing of the ITS1-5.8S-ITS2 region of rDNA is currently used to identify accurately species of this genus.

Only five cases of superficial and invasive mucormycosis involving Actinomucor have been described in the literature since 2001. Two cases were associated with maxillary sinusitis in an immunocompetent 11 -year-old female ${ }^{5}$ and in an allogeneic transplant patient with a lymphoblastic lymphoma; ${ }^{6}$ a third case was a necrotic foot lesion in a diabetic patient. ${ }^{7}$ Disseminated infection was diagnosed in two cases following a trauma during combat in $\operatorname{Iran}^{8}$ and in a diabetic patient with refractory aplasic anemia. ${ }^{9}$ Out of five patients, two were cured with surgery debridement and amphotericin B administration, ${ }^{5,6}$ two died despite debridement and broad spectrum antifungal, ${ }^{8,9}$ and one was lost to follow-up. ${ }^{7}$

\section{Apophysomyces mexicanus}

Among the subphylum Mucoromycotina, the Apophysomyces species complex ${ }^{10}$ encompasses five species: A. elegans, A. variabilis, A. trapeziformis, A. ossiformis, and the most recently proposed A. mexicanus. ${ }^{11}$ The members of this complex are mainly soil thermophilic microorganisms with tropical to subtropical distribution and have been implicated in cases of human mucormycosis mainly in immunocompetent individuals. ${ }^{12,13}$ The most common clinical presentations are cutaneous and subcutaneous localizations following trauma, burn, invasive procedures or natural disasters. ${ }^{14}$ In the reported case of A. mexicanus, patient presented with a necrotizing fasciitis rapidly spreading despite the administration of amphotericin B and fluconazole followed by an extensive surgical debridement. Diagnosis of was achieved by identifying coenocytic hyphae during the histopathological examination of the necrotic tissue and the growth of a whitish fungal colony characteristic of mucoralean fungi. The species of Apophysomyces produce fastgrowing white to gray colonies and genus specific morpholog- ical features such as the prominent bell-shaped, vase-shaped or funnel-shaped apophyses. While smooth walled sporangiophores (including the apophyse) are a common feature of this genus, the verrucose texture of the wall in A. mexicanus constitutes its distinctive characteristic. ${ }^{11} \mathrm{~A}$ molecular approach with the amplification of the ITS1-5.8S-ITS2 region of rDNA is required to assure definite species-level identification. The biggest case series of Apophysomyces sp. reports 13 cases after cutaneous injury during a tornado in Missouri in May 2011. ${ }^{15}$ Five patients (38\%) died, however; a focus on patients treated appropriately according to guidelines (i.e., amphotericin B in combination with surgical debridement $)^{16}$ shows a treatment efficiency of $85 \%$ with only two deaths. ${ }^{15}$

\section{Saksenaea erythrospora}

Among the subphylum Mucoromycotina the genus Saksenaea comprises three species: S. vasiformis species complex, S. erythrospora and S. oblongispora. ${ }^{10}$ These cosmopolitan mucoralean organisms produce white-gray expanding colonies with a maximum temperature of $44^{\circ} \mathrm{C}$. Sporulation may be promoted by subculturing the fungus on water agar $1 \%$ or Czapek medium at $30^{\circ}$ to $37^{\circ} \mathrm{C} .{ }^{4}$ The multispored flask-shaped sporangium is characteristic of the genus. Species recognition is based mainly on differences in length of sporangiophores and sporangia; shape and size of sporangiophores and maximum growth temperatures. Accurate species identification also relies on sequencing of the ITS1-5.8S-ITS2 region and the D1-D2 domains of the largesubunit ribosomal DNA. Mucormycosis due to Saksenaea spp. have been mostly associated with cutaneous infections in healthy and immunocompetent subjects following traumatic implantation with soil and water contamination, inhalation of spores, insect stings, or the use of indwelling catheters. ${ }^{17,18} \mathrm{Up}$ to now, nine cases of the newly described species $S$. erythrospora have been reported. The majority of infections were observed in immunocompetent individuals (except for one diabetic patient) ${ }^{19}$ and were associated with trauma (sailing accident, combat trauma, intramuscular injection or application of medicated adhesive tape), ${ }^{19-21}$ medical tourism activities (esthetical surgery) or invasive rhinosinusitis. ${ }^{22,23}$ Clinical presentations included necrotic or ulcerative skin and soft tissue lesions, necrotizing fasciitis, or orbital cellulitis. No specific management has been recommended in recent guidelines for Saksenaea sp. compared to other mucormycosis. As first line therapy, a combination of surgical debridement when feasible and the administration of a lipid formulation of amphotericin B, which offers a better chance of survival to the patient, have been recommended. ${ }^{16,24}$

\section{Hormographiella aspergillata}

H. aspergillata is the asexual form of Coprinopsis cinerea, a common basidiomycete found in compost. ${ }^{25}$ This fungus has been 
Table 1. Macroscopic and microscopic features of emerging fungal species in IFls.

\begin{tabular}{|c|c|c|c|c|c|c|}
\hline \multirow[b]{2}{*}{ Genus } & \multicolumn{2}{|c|}{ Macroscopic aspect in culture } & \multicolumn{2}{|c|}{ Microscopic aspect in culture } & \multicolumn{2}{|l|}{ Microscopic aspect in tissue } \\
\hline & Description & Image & Description & Image & Description & Image \\
\hline $\begin{array}{l}\text { Actinomucor } \\
\text { spp. }\end{array}$ & $\begin{array}{l}\text { White to cream floccose } \\
\text { colonies }\end{array}$ & Fig. 1A & $\begin{array}{l}\text { Verticillately branched } \\
\text { sporangiophores; smooth or } \\
\text { spiny sporangia }\end{array}$ & Fig. 1B & $\begin{array}{l}\text { Intravasculaire and parenchymal } \\
\text { invasive, ribbon-like, branching } \\
\text { fungal elements characteristics of } \\
\text { the member of Mucorales species }\end{array}$ & 8,9 \\
\hline $\begin{array}{l}\text { Apophysomyces } \\
\text { mexicanus }\end{array}$ & $\begin{array}{l}\text { White to gray rapid } \\
\text { growing colonies }\end{array}$ & ND & $\begin{array}{l}\text { Verrucose-walled } \\
\text { sporangiophores and apophyse }\end{array}$ & 11 & Wide coenocytic mycelia & 11 \\
\hline $\begin{array}{l}\text { Saksenaea } \\
\text { erythrospora }\end{array}$ & $\begin{array}{l}\text { White to gray expanding } \\
\text { colonies }\end{array}$ & 19,21 & $\begin{array}{l}\text { Multispored flask-shaped } \\
\text { sporangium }\end{array}$ & Fig. 1F & $\begin{array}{l}\text { Broad aseptate hyphae with } \\
\text { wide angle branching }\end{array}$ & 19,21 \\
\hline $\begin{array}{l}\text { Hormographiella } \\
\text { aspergillata }\end{array}$ & $\begin{array}{l}\text { White to cream cotton-like } \\
\text { colonies }\end{array}$ & 27,28 & $\begin{array}{l}\text { Septate conidiophores/clusters of } \\
\text { smooth-walled hyaline and } \\
\text { cylindrical arthroconidia }\end{array}$ & 27,28 & $\begin{array}{l}\text { Hyaline hyphae with acute } \\
\text { branching } \\
\text { Necrotic tissue }\end{array}$ & 27,28 \\
\hline $\begin{array}{l}\text { Trametes } \\
\text { polyzona }\end{array}$ & White and cottony colonies & 31 & $\begin{array}{l}\text { Hyaline septate hyphae and } \\
\text { rectangular arthroconidia }\end{array}$ & 30 & $\begin{array}{l}\text { Septate fungal hyphae } \\
\text { Neutrophil tissue infiltration }\end{array}$ & 31 \\
\hline $\begin{array}{l}\text { Emergomyces } \\
\text { africanus }\end{array}$ & $\begin{array}{l}\text { Mycelial phase }\left(25-30^{\circ} \mathrm{C}\right) \\
\text { Light brown wrinkled } \\
\text { colony with powdery } \\
\text { segment } \\
\text { Yeast phase }\left(37^{\circ} \mathrm{C}\right) \\
\text { Smooth cream-to-beige } \\
\text { color colony }\end{array}$ & Fig. 1C & $\begin{array}{l}\text { Mycelial phase: Septate hyaline } \\
\text { hyphae with numerous } \\
\text { smooth-walled oval conidia } \\
\text { borne on thin pedicles. } \\
\text { Yeast phase: Small thin-walled, } \\
\text { globose-to-oval yeasts }(2-4 \mu \mathrm{m} \\
\text { in diameter) }\end{array}$ & Fig. 1D & $\begin{array}{l}\text { Round to ovoid yeasts with } \\
\text { single budding nuclei and thin } \\
\text { walls simulating Histoplasma } \\
\text { capsulatum }\end{array}$ & 54 \\
\hline $\begin{array}{l}\text { Rhytidhysteron } \\
\text { rufulum }\end{array}$ & $\begin{array}{l}\text { Dark green to grey velvety } \\
\text { colonies }\end{array}$ & Fig. 1E & $\begin{array}{l}\text { Septate irregularly branched } \\
\text { dematiaceus hyphae Ascomata } \\
\text { apothecioid, Ascospores } \\
\text { transversely } 3 \text {-septate, with no } \\
\text { longitudinal septa }\end{array}$ & 39,41 & $\begin{array}{l}\text { Thick-walled brown, spherical, } \\
\text { sclerotic bodies with or without } \\
\text { septation }\end{array}$ & 39,41 \\
\hline $\begin{array}{l}\text { Scopulariopsis } \\
\text { (Microascus) } \\
\text { spp. }\end{array}$ & $\begin{array}{l}\text { Powdery pale brown } \\
\text { colonies }\end{array}$ & Fig. $1 \mathrm{G}$ & $\begin{array}{l}\text { Septate hyphae, annellidic } \\
\text { conidiogenous cells in chains } \\
\text { and smooth or rough-walled } \\
\text { subglobose conidia with a } \\
\text { flattened base. }\end{array}$ & Fig. $1 \mathrm{H}$ & $\begin{array}{l}\text { Irregularly shaped hyphae with } \\
\text { swollen thick-walled structure } \\
\text { Angioinvasive } \\
\text { Necrotic tissue formation } \\
\text { May be melanized }\end{array}$ & 43,45 \\
\hline $\begin{array}{l}\text { Westerdykella } \\
\text { dispersa }\end{array}$ & $\begin{array}{l}\text { Dark-brown colonies with } \\
\text { dark globose cleistothecium }\end{array}$ & Fig. 1I & $\begin{array}{l}\text { Reddish-brown, smooth, } \\
\text { cylindrical to slightly reniform } \\
\text { ascospores Pycnidia with ostioles } \\
\text { and subglobose to pyriform, } \\
\text { hyaline conidia }\end{array}$ & $\begin{array}{l}\text { Fig. 1J } \\
\text { Fig. } 1 \mathrm{~K}\end{array}$ & septate hyphal angioinvasive & 48 \\
\hline
\end{tabular}

ND, not described.

reported in 15 cases in the past two decades and majorly arises in neutropenic patients who underwent allogeneic stem cell transplantation as part of acute leukemia treatment. ${ }^{26,27}$ Clinical presentation is an invasive pulmonary infection in all cases but one has been described to disseminate to the central nervous system (CNS), eyes, skin, sinuses, and blood (endocarditis). ${ }^{28}$ Diagnosis is driven by the presence of nodular infiltrates and the halo sign on pulmonary computed tomography $(\mathrm{CT})$. Galactomannan is constantly negative and bronchoalveolar lavage (BAL) is always negative Table( 2). ${ }^{29}$ Thoracoscopic surgery and lung biopsy allowed to have final diagnosis in all cases allowing the growth of H. aspergillata in all cases in which it was performed. ${ }^{26,29}$ The morphological characteristics of the fungus are described in Table 1. This fungus responds poorly to all antifungal and mortality rate of all cases published is $73 \% .^{25,26}$ In vitro susceptibility shows intrinsic resistance to echinocandins and variable minimal inhibitory concentration (MIC) to second generation azoles and amphotericin $\mathrm{B}(\mathrm{AmB})$, but these data cannot be translated into clinical practice without caution. The addition of nebulized liposomal-AmB (L-AmB) to IV L-AmB is the treatment combination that showed the best improvement of a patient condition so far. $^{26}$ 

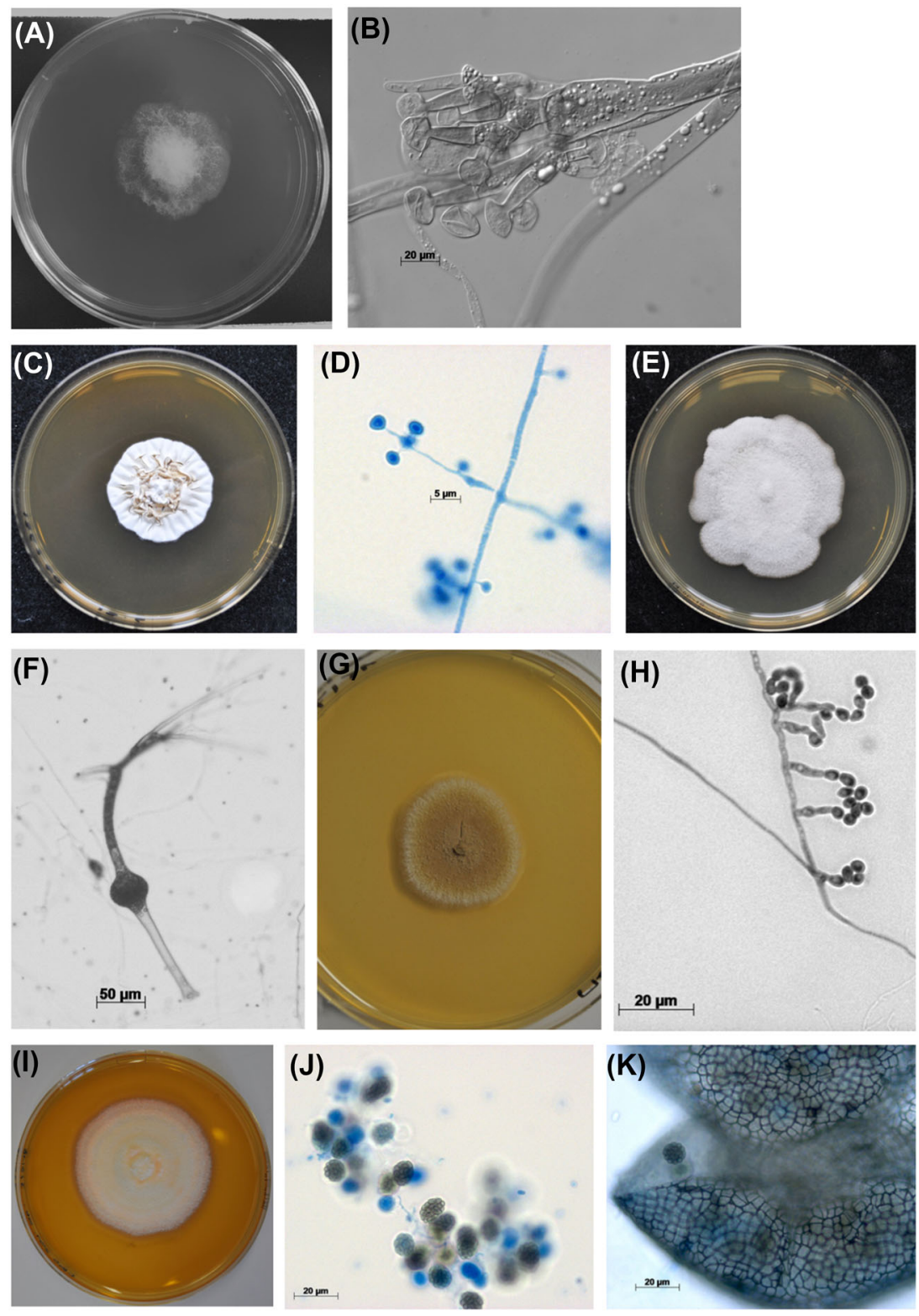

Figure 1. Actinomucor elegans (A) floccose colony on MEA $2 \%$ after 3 days of incubation at $30^{\circ} \mathrm{C}$ (B) microscopic aspect of sporangiophores terminating in columellae. Emergomyces africanus (C) restricted colony on MEA $2 \%$ after 10 days at $24^{\circ} \mathrm{C}$ (D) microscopy of slide culture on MEA $2 \%$ after 7 days at $24^{\circ} \mathrm{C}$; solitary conidiophores and subspherical conidia. Rhytidhysteron rufulum (E) velvety colony on MEA $2 \%$ after 15 days at $21^{\circ} \mathrm{C}$. Saksenaea erythrospora (F) sporangiophore, flask-shaped sporangia and rhizoïds after 15 days on Czapek agar at $30^{\circ} \mathrm{C}$. Scopulariopsis brevicaulis (G) brown powdery colony on MEA $2 \%$ after 10 days at $30^{\circ} \mathrm{C}$. Microascus cirrosus $(\mathrm{H})$ annelated conidiophores and conidia after 7 days on MEA $2 \%$ at $30^{\circ} \mathrm{C}$. Westerdykella dispersa (I) expanding colony on MEA $2 \%$ after 7 days at $30^{\circ} \mathrm{C}(\mathrm{J})$ reddish brown cylindrical ascospores $(\mathrm{K})$ dark globose cleistothecium and reddish brown cylindrical ascospores. MEA2\%: Malt extract agar $2 \%$.

\section{Trametes polyzona}

Trametes polyzona is a basidomycete that belongs to the order Polyporales. It is a saprotrophic fungi that has been isolated in Africa, South and Central America, and Asia being particularly prevalent in tropical countries and playing a major role as a decomposer in the tropical forest ecosystem. ${ }^{30}$ The first report in human infections was in 2016 from two cases of pneumonia ${ }^{31}$ in Reunion island. Patients suffered from chronic debilitating diseases that lead to fungal colonization of the respiratory tract. They were initially treated with caspofungin or fluconazole and later with liposomal amphotericin B. Histopathological confirmation was obtained in one case. The isolates recovered from both cases did not sporulate in standard culture and were identified by sequencing informative targets. Antifungal susceptibility testing revealed low MICs $(<0.5 \mathrm{mg} / \mathrm{l})$ to amphotericin B and azoles but high MICs (>8 mg/l) for caspofungin and terbinafine. 
Table 2. Results of routinely used biological fungal markers in invasive fungal disease of emergent fungi.

\begin{tabular}{|c|c|c|c|c|c|}
\hline & $\begin{array}{c}\text { ß-D-glucan } \\
\text { Number of positive } \\
\text { patient }(n)\end{array}$ & $\begin{array}{c}\text { GM serum } \\
\text { Number of positive } \\
\text { patient }(n)\end{array}$ & $\begin{array}{c}\text { GM BAL } \\
\text { Number of positive } \\
\text { patient }(n)\end{array}$ & $\begin{array}{l}\text { Urine Histoplasma } \\
\text { Ag } \\
\text { Number of positive } \\
\text { patient }(n)\end{array}$ & Reference \\
\hline Actinomucor spp. & NA & $1(1)$ & NA & NA & 6 \\
\hline $\begin{array}{l}\text { Apophysomyces } \\
\text { mexicanus }\end{array}$ & NA & NA & NA & NA & \\
\hline $\begin{array}{l}\text { Saksaenae } \\
\text { erythrospora }\end{array}$ & NA & NA & NA & NA & \\
\hline $\begin{array}{l}\text { Hormographiella } \\
\text { aspergillata }\end{array}$ & $0(1)$ & $0(7)$ & $0(4)$ & NA & $26-29$ \\
\hline Trametes polyzona & NA & NA & NA & NA & \\
\hline $\begin{array}{l}\text { Emergomyces } \\
\text { africanus }\end{array}$ & NA & NA & NA & $3(10)$ & 54 \\
\hline $\begin{array}{l}\text { Rhytidbysteron } \\
\text { rufulum }\end{array}$ & $\mathrm{NA}^{*}$ & $\mathrm{NA}^{* *}$ & NA & NA & \\
\hline $\begin{array}{l}\text { Scopulariopsis } \\
\text { (Microascus) spp. }\end{array}$ & $0(1)$ & $0(2)$ & $0(1)$ & NA & 45,55 \\
\hline $\begin{array}{l}\text { Westerdykella } \\
\text { dispersa }\end{array}$ & NA & $0(1)$ & NA & NA & 48 \\
\hline
\end{tabular}

Ag, antigen; BAL, broncho-alveolar lavage; GM, galactomannan; NA, no assessment.

${ }^{*} 1(1)$ in an unpublished case in $2018 ;{ }^{* *} 0$ (1) in an unpublished case in 2018.

\section{Emergomyces spp.}

For more than 50 years, the genus Emmonsia was known to cause a rare disease called adiaspiromycosis. ${ }^{32}$ While the incidence of adiaspiromycosis does not seem to increase, an outbreak of Emmonsia-like fungi has been causing severe disseminated infection in South African human immunodeficiency virus (HIV) patients in the past 10 years. ${ }^{33}$ Considering that these fungi do not produce adiaspores in tissue, display thermal dimorphism and generate disseminated disease in immunocompromised patients, a new genus called Emergomyces has been proposed supported by molecular investigations. ${ }^{34}$ Emergomyces accommodates former Emmonsia pasteuriana, and the new species Emergomyces africanus responsible for the South African outbreak $^{34}$ and Emergomyces orientalis only described in a case in China. ${ }^{35}$ Emergomyces pasteuriana, ex-Emmonsia pasteuriana, has been reported in five cases since $1998,{ }^{36}$ while E. africanus has been responsible for at least 86 reported cases in South Africa since 2008. ${ }^{35}$ Both present as a disseminated infections with skin lesions in AIDS patients with a CD4 cell count $<100 / \mathrm{mm}^{3}$. Clinical presentation of E. africanus, whose infection has been recently well described, associates fever, weight loss, anemia, and widespread nonspecific skin lesions from erythematous papules to ulcers and crusted plaques. Infection is fatal in about $30 \%$ of cases. ${ }^{33,35}$ Dissemination is documented by lesions on chest Xray resembling tuberculosis and elevated liver enzymes. Culture of skin biopsy isolates the fungus in all cases, whose characteristics are described in Table 1. Isolation of the fungus from blood or bone marrow is significantly associated with death. ${ }^{35}$ Despite the lack of guidelines on the management of emergomycosis, the fungus seems to respond well and rapidly to amphotericin B deoxycholate for 14 days followed by itraconazole maintenance therapy. ${ }^{33,35}$

\section{Rhytidhysteron rufulum}

Rhytidhysteron rufulum is a melanized ascomycete genus that has being recognized for many years as a plan pathogen. Recent molecular studies transferred the genus from Patellariaceae to the Hysteriaceae family. ${ }^{37}$ Rhydhysteron rufulum was first isolated from a human infection in 2009 in a case of chromoblastomycosis in India. ${ }^{38}$ Seven more phaeophyphomycosis cases have been described in the literature since then. ${ }^{38-42}$ Five were immunocompetent patients, one renal transplant and two diabetic patients. Diagnosis was always based on the isolation of the fungus and sequencing since the isolates do not sporulate in culture. All cases were found in the lower limbs. Patient's treatment included itraconazole alone or in combination with terbinafine and/or lesion excision. One case was also treated with amphotericin $\mathrm{B}$ in addition to lesion excision, itraconazole and terbinafine. ${ }^{39}$ Four of the cases got cured, one (chromoblastomycosis) did not, and three patients were lost to follow-up.

\section{Scopulariopsis (Microascus) spp.}

The ascomyceteous genus Scopulariopsis includes hyaline and melanized species that are ubiquitous and found in soil, air, wood, dung, and animal remains. ${ }^{43}$ Most common species involved in human pathogenicity are Scopulariopsis brevicaulis, Scopulariopsis gracilis, Scopulariopsis brumptii (recently 
renamed as Microascus gracilis and Microascus paisii respectively), Scopulariopsis candida, Microascus cirrosus and Microascus cinereus. ${ }^{43}$ They are occasionally involved in human infections ranging from superficial infections (onychomychosis, keratitis, otomycosis) to invasive infections with high mortality rates. The latter include endocarditis, sinusitis, brain abscess, pulmonary, deep cutaneous and disseminated cases with poor outcome, mostly seen in immunocompromised patients. ${ }^{43}$ Scopulariopsis spp. grows well on routine laboratory media and are recovered and identified easily from clinical samples (Table 1). Fungal biological markers are also usually negative in disseminated infection (Table 2). Infections by Scopulariopsis spp. lack recommendation guidelines related to high in vitro MICs (minimum inhibitory concentrations) to all current antifungal agents. ${ }^{44}$ Furthermore, many cases report discrepancies between MIC in vitro and clinical response suggesting that some antifungals, mainly amphotericin B and voriconazole, may be active in patients, as observed in fusariosis with voriconazole. ${ }^{44,45}$ Surgery combined with antifungal is usually advised to give patients the highest chance of survival. ${ }^{44,45}$

\section{Westerdykella dispersa}

Westerdykella spp. are saprobic fungi with a worldwide distribution. It belongs to the family Sporomiaceae (order Pleosporales). It has been described as the causative agent of systemic infection in dogs. ${ }^{46}$ Two cases of human infections have been reported until now. ${ }^{47,48}$ Sue et al. reported the infection in a neutropenic patient with acute lymphoblastic leukemia. ${ }^{48}$ Infectious complication around a peripherally inserted central catheter occurred. The patient was successfully treated with a combination of voriconazole and liposomal amphotericin B in addition to repeated debridements. The second case was isolated from a critically burned patient. ${ }^{47}$ Three other isolates were recovered from lower extremity wounds or tissue in the United States identified as Westerdykella, one of them as W. dispersa and the other two as W. reniformis. ${ }^{48}$ However, their virulence in these cases has not been acknowledged.

\section{Discussion}

New mould species are increasingly reported as responsible for IFIs in humans. Some belong to newly described genus such as Emergomyces spp., but some are well-known fungi never encountered in human disease before like $H$. aspergillata. On one hand, the use of antifungal therapy necessarily gives rise to the emergence of naturally resistant species. In addition, antifungal prophylaxis with azoles in at-risk patients has been shown to select for resistant species such as Mucorales or Scopulariopsis spp. ${ }^{49,50}$ In patients empirically treated with echinocandins, the most common antifungal class for the treatment of candidemia, invasive mould infection may also arise. ${ }^{27} \mathrm{New}$ classes of antifungals are needed to treat and prevent these naturally resistant emerging species in immunocompromised patients. On the other hand, introduction and improvement of biomolecular techniques to identify mould and yeast species may create a reporting bias, since these techniques, following recommendations on fungal barcoding, are able to detect more species that are misidentified by classical methods previously used. ${ }^{51,52}$

In the light of new diagnostic methods, including fungal biomarkers and polymerase chain reaction (PCR) techniques, microscopic identification skills tend to be overlooked. However, a thorough direct examination of patient samples not only can catch and orientate towards a fungal group (yeast, hyalohyphomycetes, Mucorales) but also remains the fastest result to help initiate early treatment as a mean to improve prognosis. Furthermore, a direct observation of fungal elements in tissue is a strong evidence to prove an invasive fungal infection according to the EORTC criteria. ${ }^{53}$ Considering that infections by emerging fungi are difficult cases to diagnose, they may therefore be under reported.

\section{Acknowledgments}

We thank Françoise Dromer and Stéphane Bretagne for their continuous support.

\section{Declaration of interest}

The authors report no conflicts of interest. The authors alone are responsible for the content and the writing of the paper.

\section{References}

1. Vallabhaneni S, Mody RK, Walker T, Chiller T. The global burden of fungal diseases. Infect Dis Clin N Am. 2016; 30: 1-11.

2. Karimi K, Arzanlou M, Ahari AB, Ghazi MM. Phenotypic and molecular characterization of the causal agent of chafer beetle mortality in the wheat fields $\mathrm{f}$ the Kurdistan province, Iran. J Plant Protect Res. 2015; 55: 227-234.

3. Han B-Z, Kuijpers AFA, Thanh NV, Nout MJR. Mucoraceous moulds involved in the commercial fermentation of Sufu Pehtze. Antonie van Leeuwenhoek. 2004; 85: 253-257.

4. Garcia-Hermoso D, Dromer F, Alanio A, Lortholary O. Agents of systemic and subcutaneous mucormycosis and entomophthoromycosis. In: Manual of Clinical Microbiology, 11th edn. Washington, DC: American Society of Microbiology, 2015: 2087-2108.

5. Davel G, Featherston P, Fernandez A et al. Maxillary sinusitis caused by Actinomucor elegans. J Clin Microbiol. 2001; 39: 740-742.

6. Dorin J, D'Aveni M, Debourgogne A et al. Update on Actinomucor elegans, a mucormycete infrequently detected in human specimens: how combined microbiological tools contribute efficiently to a more accurate medical care. Int J Med Microbiol. 2017; 307: 435-442.

7. Khan ZU, Ahmad S, Mokaddas E, Chandy R, Cano J, Guarro J. Actinomucor elegans var. kuwaitiensis isolated from the wound of a diabetic patient. Antonie van Leeuwenhoek. 2008; 94: 343-352.

8. Tully CC, Romanelli AM, Sutton DA, Wickes BL, Hospenthal DR. Fatal Actinomucor elegans var. kuwaitiensis infection following combat trauma. J Clin Microbiol. 2009; 47: 3394-3399.

9. Mahmud A, Lee R, Munfus-McCray D et al. Actinomucor elegans as an emerging cause of mucormycosis. J Clin Microbiol. 2012; 50: 1092-1095.

10. Alvarez E, Stchigel AM, Cano J et al. Molecular phylogenetic diversity of the emerging mucoralean fungus Apophysomyces: proposal of three new species. Revista Iberoamericana de Micología. 2010; 27: 80-89. 
11. Bonifaz A, Stchigel AM, Guarro J et al. Primary cutaneous mucormycosis produced by the new species Apophysomyces mexicanus. J Clin Microbiol. 2014; 52: 4428-4431.

12. Garcia-Covarrubias L, Bartlett R, Barratt DM, Wassermann ARJ. Rhinoorbitocerebral mucormycosis attributable to Apophysomyces elegans in an immunocompetent individual: case report and review of the literature. $J$ Trauma. 2001; 50: 353-357.

13. Chakrabarti A, Shivaprakash MR, Curfs-Breuker I, Baghela A, Klaassen $\mathrm{CH}$, Meis JF. Apophysomyces elegans: epidemiology, amplified fragment length polymorphism typing, and in vitroantifungal susceptibility pattern. J Clin Microbiol. 2010; 48: 4580-4585.

14. Gomes MZR, Lewis RE, Kontoyiannis DP. Mucormycosis caused by unusual mucormycetes, non-Rhizopus, -Mucor, and-Lichtheimia species. Clin Microbiol Rev. 2011; 24: 411-445.

15. Neblett-Fanfair R, Benedict K, Bos J et al. Necrotizing cutaneous mucormycosis after a tornado in Joplin, Missouri, in 2011. N Engl J Med. 2012; 367: 2214 2225.

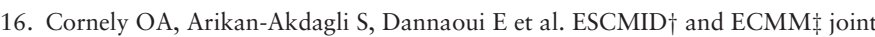
clinical guidelines for the diagnosis and management of mucormycosis 2013. Clin Microbiol Infect. 2014; 20: 5-26.

17. Chakrabarti A, Kumar P, Padhye AA et al. Primary cutaneous zygomycosis due to Saksenaea vasiformis and Apophysomyces elegans. Clin Infect Dis. 1997; 24: 580-582.

18. Spellberg B, Edwards J, Ibrahim A. Novel perspectives on mucormycosis: pathophysiology, presentation, and management. Clin Microbiol Rev. 2005; 18: 556569

19. Chander J, Singla N, Kaur M et al. Saksenaea erythrospora, an emerging mucoralean fungus causing severe necrotizing skin and soft tissue infections: a study from a tertiary care hospital in north India. Infect Dis. 2016; 49: 170-177.

20. Relloso S, Romano V, Landaburu MF et al. Saksenaea erythrospora infection following a serious sailing accident. J Med Microbiol. 2014; 63: 317-321.

21. Hospenthal DR, Chung KK, Lairet K et al. Saksenaea erythrospora infection following combat trauma. J Clin Microbiol. 2011; 49: 3707-3709.

22. Rodríguez JY, Rodríguez GJ, Morales-López SE, Cantillo CE, Le Pape P, ÁlvarezMoreno CA. Saksenaea erythrospora infection after medical tourism for esthetic breast augmentation surgery. Int J Infect Dis. 2016; 49: 107-110.

23. Bradoo R, Baveja S, Tendolkar U et al. Rhinosinusitis caused by Saksenaea erythrospora in an immunocompetent patient in India: a first report. JMM Case Reports. 2015; 2: 4410.

24. Lortholary O, Fernández-Ruiz M, Perfect JR. The current treatment landscape: other fungal diseases (cryptococcosis, fusariosis and mucormycosis). J Antimicrob Chemother. 2016; 71: ii31-ii36.

25. Chowdhary A, Kathuria S, Agarwal K, Meis JF. Recognizing filamentous basidiomycetes as agents of human disease: a review. Med Mycol. 2014; 52: 782-797.

26. Godet C, Cateau E, Rammaert B et al. Nebulized liposomal amphotericin B for treatment of pulmonary infection caused by Hormographiella aspergillata: case report and literature review. Mycopathologia. 2017; 182: 709-713.

27. Suarez F, Olivier G, Garcia-Hermoso D et al. Breakthrough Hormographiella aspergillata infections arising in neutropenic patients treated empirically with caspofungin. J Clin Microbiol. 2010; 49: 461-465.

28. Nanno S, Nakane T, Okamura $\mathrm{H}$ et al. Disseminated Hormographiella aspergillata infection with involvement of the lung, brain, and small intestine following allogeneic hematopoietic stem cell transplantation: case report and literature review. Transplant Infect Dis. 2016; 18: 611-616.

29. Conen A, Weisser M, Hohler D, Frei R, Stern M. Hormographiella aspergillata: an emerging mould in acute leukaemia patients? Clin Microbiol Infect. 2011; 17 273-277.

30. Zmitrovich IV, Ezhov ON, Wasser SP. A survey of species of genus Trametes fr. (higher Basidiomycetes) with estimation of their medicinal source potential. Int J Med Mushrooms. 2012; 14: 307-319.

31. Gauthier A, Jaubert J, Traversier $\mathrm{N}$ et al. Trametes polyzona, an emerging filamentous basidiomycete in Réunion Island. Mycoses. 2017; 60: 412-415.

32. Schwartz IS, Kenyon C, Feng P et al. 50 Years of Emmonsia disease in humans: the dramatic emergence of a cluster of novel fungal pathogens. PLoS Pathogens. 2015; 11: e1005198-e1005198.

33. Kenyon C, Bonorchis K, Corcoran $\mathrm{C}$ et al. A dimorphic fungus causing disseminated infection in South Africa. N Engl J Med. 2013; 369: 1416-1424.
34. Dukik K, Muñoz JF, Jiang Y et al. Novel taxa of thermally dimorphic systemic pathogens in the Ajellomycetaceae (Onygenales). Mycoses. 2017; 60: 296-309.

35. Maphanga TG, Britz E, Zulu TG et al. In vitro antifungal susceptibility of yeast and mold phases of isolates of dimorphic fungal pathogen Emergomyces africanus (formerly Emmonsia sp.) from HIV-infected South African patients. J Clin Microbiol. 2017; 55: 1812-1820.

36. Malik R, Capoor MR, Vanidassane I et al. Disseminated Emmonsia pasteuriana infection in India: a case report and a review. Mycoses. 2015; 59: 127-132.

37. Boehm EWA, Mugambi GK, Miller AN et al. A molecular phylogenetic reappraisal of the Hysteriaceae, Mytilinidiaceae and Gloniaceae (Pleosporomycetidae, Dothideomycetes) with keys to world species. Stud Mycol. 2009; 64: 49-83.

38. Chowdhary A, Guarro J, Randhawa HS et al. A rare case of chromoblastomycosis in a renal transplant recipient caused by a non-sporulating species of Rhytidhysteron. Med Mycol. 2008; 46: 163-166.

39. Mahajan VK, Sharma V, Prabha N et al. A rare case of subcutaneous phaeohyphomycosis caused by a Rhytidhysteron species: a clinico-therapeutic experience. Int J Dermatol. 2014; 53: 1485-1489.

40. Mishra K, Das S, Goyal S et al. Subcutaneous mycoses caused by Rhytidhysteron species in an immunocompetent patient. Med Mycol Case Rep. 2014; 5: 32-34.

41. Chander J, Singla N, Kundu R, Handa U, Chowdhary A. Phaeohyphomycosis caused by Rhytidhysteron rufulum and review of literature. Mycopathologia. 2016; 182: 1-5.

42. Mudhigeti N, Patnayak R, Kalawat U, Yeddula SRC. Subcutaneous Rhytidhysteron infection: a case report from South India with literature review. Cureus. 2018; 10: 1-9.

43. Iwen PC, Schutte SD, Florescu DF, Noel-Hurst RK, Sigler L. Invasive Scopulariopsis brevicaulis infection in an immunocompromised patient and review of prior cases caused by Scopulariopsis and Microascus species. Med Mycol. 2012; 50: 561-569.

44. Paredes K, Capilla J, Mayayo E, Guarro J. Virulence and resistance to antifungal therapies of Scopulariopsis species. Antimicrob Agents Chemother. 2016; 60: 2063-2068.

45. Gavril D, Woerther P-L, Ben Lakhdar A et al. Invasive cutaneous infection due to Scopulariopsis brevicaulis unsuccessfully treated with high-dose micafungin in a neutropenic patient. Infection. 2017; 45: 361-363.

46. Armentano RA, American KCJOT, 2013. Disseminated mycotic infection caused by Westerdykella species in a German Shepherd dog. Am Vet Med Assoc. 2013; 242: 381-387.

47. Lipovy B, Kocmanova I, Holoubek J et al. The first isolation of Westerdykella dispersa in a critically burned patient. Folia Microbiol. 2018; 63: 1-4.

48. Sue PK, Gurda GT, Lee R et al. First report of Westerdykella dispersa as a cause of an angioinvasive fungal infection in a neutropenic host. J Clin Microbiol. 2014; 52: 4407-4411.

49. Lamoth F, Chung SJ, Damonti L, Alexander BD. Changing epidemiology of invasive mold infections in patients receiving azole Prophylaxis. Clin Infect Dis. 2017; 64: 1619-1621.

50. Danion F, Aguilar C, Catherinot E et al. Mucormycosis: new developments into a persistently devastating infection. Semin Respir Crit Care Med. 2015; 36: 692705.

51. Schoch CL, Seifert KA, Huhndorf S et al. Nuclear ribosomal internal transcribed spacer (ITS) region as a universal DNA barcode marker for Fungi. Proc Natl Acad Sci U S A. 2012; 109: 6241-6246.

52. Stielow JB, Lévesque CA, Seifert KA et al. One fungus, which genes? Development and assessment of universal primers for potential secondary fungal DNA barcodes. Pers - Int Mycol J. 2015; 35: 242-263.

53. De Pauw B, Walsh TJ, Donnelly JP et al. Revised definitions of invasive fungal disease from the European organization for research and treatment of cancer/invasive fungal infections cooperative group and the national institute of allergy and infectious diseases Mycoses Study Group (EORTC/MSG) Consensus Group. Clin Infect Dis. 2008; 46: 1813-1821.

54. Schwartz IS, Kenyon C, Lehloenya R et al. AIDS-related endemic mycoses in Western Cape, South Africa, and clinical mimics: a cross-sectional study of adults with advanced HIV and recent-onset, widespread skin lesions. Open Forum Infect Dis. 2017; 4: ofx186.

55. Rose SR, Vallabhajosyula S, Velez MG et al. The utility of bronchoalveolar lavage beta-D-glucan testing for the diagnosis of invasive fungal infections. $J$ Infect. 2014; 69: 278-283. 